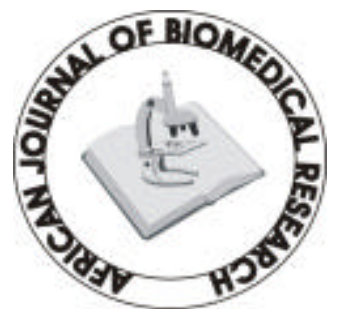

Full-text available at http://www.ajbrui.com \&

http://www.bioline.br/md
Full Length Research Article

\section{Neuropharmacological Effects of Aqueous Leaf Extract of Bryophyllum Pinnatum in Mice}

\author{
${ }^{1}$ Salahdeen* H.M and ${ }^{2}$ Yemitan O.K \\ ${ }^{1}$ Departments of Physiology and ${ }^{2}$ Pharmacology \\ Lagos State University College of Medicine, \\ P. M. B. 21266, Ikeja. Lagos, Nigeria
}

\section{ABSTRACT}

Effects of aqueous leaf extracts of bryophyllum pinnatum (AEBP) on some neuropharmacological activities were studied in mice. The extract in dosages $(50,100$ and $200 \mathrm{mg} / \mathrm{kg}$ ) was found to produce a profound decrease in exploratory activity in a dose-dependent manner. It also showed a marked sedative effect as evidenced by a significant reduction in gross behaviour and potentiation of pentobarbitone-induced sleeping time. It delayed onset in strychnine-and picrotoxin-induced convulsion (seizures) respectively with the protective effect being significantly higher in picrotoxin-than strychnine-induced convulsion. It also decreases the rate of picrotoxin-induced mortality in mice with $L D_{50}$ of $641 \mathrm{mg} / \mathrm{kg}$. The totality of these effects showed that the extract possesses depressant action on the central nervous system

Keywords: Bryophyllum pinnatum, Neuropharmacology, exploration, anticonvulsant, muscle relaxant.

*Address for Correspondence (e-mail): hmsalahdeen@yahoo.ca

Abstracted by:

African Index Medicus (WHO), CAB Abstracts, Global Health Abstracts, Asian Science Index, Index Veterinarius, Protozoological Abstracts 


\section{INTRODUCTION}

Traditional medicine involves the use of herbal medicine, animal parts and minerals. However, herbal medicines are the most widely used of the three.

Herbal medicines contain an active ingredient, aerial or underground parts of plants as their petal or seeds materials or combinations thereof, whether in the crude state or as plant preparations. Furthermore, about $80 \%$ of the world population is dependent (wholly or partially) on plant-based drugs (WHO, 1996). In Nigeria and most developing countries of the world, rural and urban dwellers, literate or illiterate rely heavily on herbal preparations for the treatment of various diseases despite the availability of orthodox medicine (Nwabuise, 2002).

Bryophyllum pinnatum (Lam.) (synonym: Kalanchoe pinnata, Lam.; common names: Life plant, air plant (Mexican), love plant, Canterbury bells, Cathedral bells, e.t.c) is a perennial herb growing widely and used in folkloric medicine in tropical Africa, India, China, Australia and tropical America (Engler, 1926; Balzer et al, 1949). Classified as a weed (Oliver-Bever, 1983), the plant flourishes throughout the Southern part of Nigeria (Gill, 1992). A number of active compounds, including flavonoids, glycosides, steroids, bufadienolides and organic acids, have been identified in Bryophyllum pinnatum (Marriage and Wilson, 1971; Gaind and Gupta, 1972; 1974; Costa et al, 1995).

In traditional medicine, the leaves of this plant have been reported to possess antimicrobial (Mehta and Bhat, 1952; Akinpelu, 2000; Oliver-Bever, 1983), antifungal (Misra and Dixit, 1979), anti ulcer (Pal and $\mathrm{Nag}, 1991)$, anti-inflammatory and analgesic (Pal and Nag, 1989; 1992), and antihypertensive (Ojewole 2002) activities. The methanol extract of the leaf of the plant has also been reported to have histamine receptor $\left(\mathrm{H}_{1}\right)$ antagonism in the ileum, peripheral vasculature and bronchial muscle (Pal et al, 1999)

Although, studies have shown the relative important effect of some medicinal plant on the central nervous system activities. (Dorr et al., 1971; Fujimori, 1995; Wakeel, 2004).. B. pinnatum has been used since 1921 in traditional medicine as an antipsychotic agent. Furthermore, Pal and Nag (1999) provided evidence for the neuropsychopharmacologic activities of the plant. The present study is therefore designed to further investigate the effects of the aqueous leaf extract of $B$. pinnatum on some central nervous system activities in mice.

\section{MATERIALS AND METHODS}

Plant Material: Fresh leaves of B. pinnatum were collected from botanical garden of the Lagos State University College of Medicine, Ikeja - Lagos, Nigeria, and were identified and authenticated by T.K Odewo Assistant Chief Superintendent Officer, Forestry Research Institute of Nigeria (FRIN) Ibadan, Nigeria. The voucher specimen was deposited at the FRIN Herbarium.

Extract preparation: The plant extract was prepared by blending and macerating $500 \mathrm{~g}$ of the fresh leaves of $B$. pinnatum with $100 \mathrm{ml}$ of distilled water and was kept at $40^{\circ} \mathrm{C}$ for 24 hours for extraction to take place. The resulting mixture was filtered. The concentration of the extract recovered from the filtrations was computed using the expression:

\section{Concentration $=(\mathrm{X}-\mathrm{Y}) / \mathrm{Z} \mathrm{g} / \mathrm{ml}$ \\ Where $X=$ Weight of fresh leaves before blending $Y g=$ Weight of leaves after filtration $\mathrm{Zml}=$ Volume of water after filtration}

Fresh preparation was used for each experimental run.

Animals: Swiss albino mice weighing $20-25 \mathrm{~g}$ were obtained from the Laboratory Animal Centre of the College of Medicine, Lagos State University, Ikeja Lagos, Nigeria. The animals were maintained under standard environmental conditions throughout the period of experimentation. The animals had access to water and food ad libitum. However, they were deprived of food 12 hours before experimentation. All animal experiments were carried out in accordance with Lagos State University, College of Medicine ethical committee acts.

Drugs: The drugs used were: pentobarbitone, chlorpromazine hydrochloride, diazepam, strychnine hydrochloride and picrotoxin. All drugs were purchased from Sigma Chemical Company U.S.A.

Experimental design: The animals were divided into five groups. The first groups of animals were used for the behavioural changes and acute toxicity studies. 
The second groups were used for the exploratory behaviour. The third groups were used for the pentobarbitone sleeping time. The fourth group were used also for the muscle relaxant tests. (Grp IV). The last group which is group five was used for the study of anticonvulsant activity of the aqueous extract.

Each group of animals was sub-divided into control and experimental groups, which was treated with the extract at sub-lethal doses of 50, 100, $200 \mathrm{mg} / \mathrm{kg}$ bodyweight while the control received normal saline. The vehicle and the extracts were administered intraperitoneally before the experimentation.

Behavioural change and acute toxicity studies: The method of Miller and Tainter (1944) modified by Irwin (1963) was used: 5 groups of mice $(n=8)$ after oral administration of different doses of aqueous extract of B. pinnatum $(0.1,0.5,1,1.5$ and $2 \mathrm{~g} / \mathrm{kg})$ were observed at $30 \mathrm{~min}$ intervals for $4 \mathrm{~h}$ for gross morphological and behavioural changes. For the toxicity study, 5 groups of male mice $(n=8)$ were orally administered with different doses of the leaf extract as above and the mortality was determined after $24 \mathrm{~h}$.

Exploratory behaviour: The head dip test method of File and Wardril (1975) was used, using a white printed wooden board designed $(400 \mathrm{~cm} \times 40 \mathrm{~cm})$ with four equidistant holes $(1 \mathrm{~cm}$ diameter $\mathrm{x} 2 \mathrm{~cm}$ depth). The mice were placed at the center of the board and moved freely in the box. A head dip into holes was used to indicate exploratory behaviour. The number of dip observed for 10min; the test was carried out 30 min after pre-treatment of the animal with $(50,100$, $200 \mathrm{mg} / \mathrm{kg}$ ) of B. pinnatum to various groups. Chlorpromazine hydrochloride $(4 \mathrm{mg} / \mathrm{kg}$ i.m) and normal saline were used as controls.

Evasion test: The method of Turner (1965) was used, the animals were introduced into this rectangular box with an inclined plane by which the mice can escape from the box, and the mice that escaped within 5 min from the rectangular box were selected for this test. 15 minutes after administration of normal saline, diazepam as control and B. pinnatum leaf extract (50, $100,200 \mathrm{mg} / \mathrm{kg})$ the animals $(\mathrm{n}=8)$ were placed in the box again and the number of mice remaining in the box after $15 \mathrm{~min}$ in each group was noted.
Pentobarbitone sleeping time: Groups of male mice $(n=8)$ were injected with pentobarbitone sodium $(40 \mathrm{mg} / \mathrm{kg}$ i.p) fifteen minutes after intraperitoneal administration of either normal saline and $B$. pinnatum leaf extract $(50,100$ and $200 \mathrm{mg} / \mathrm{kg}$ ), and the time interval between losing and regaining of righting reflex was measured as sleeping time (Yemitan et al, 2001).

Muscle relaxant tests: Chimney test of Boissier 1961 was used where a Pyrex glass tube $(30 \mathrm{~cm}$ long and $28 \mathrm{~mm}$ diameter) marked at a point $20 \mathrm{~cm}$ from its base; a mouse was introduced at the end, nearest the mark. When the animal reached the other end of the tube, the tube was moved to the vertical position and immediately the mouse tried to climb backwards. Only those mice that reached the mark within 30s were selected for further testing. Screened mice were injected intraperitoneally with vehicle or $B$. pinnatum leaf extract $(50,100,200 \mathrm{mg} / \mathrm{kg})$ and were tested after $15 \mathrm{~min}$ as described above.

Climbing Test: Mice were previously trained to climb a chain of $(6 \mathrm{~cm}$ long) suspended from a clamp of a retort stand $(100 \mathrm{~cm}$ above ground). Only those mice that climbed the chain within 10s were selected for the test. This test was carried out $30 \mathrm{~min}$ after treatment with $B$. pinnatum and diazepam and normal saline were used as control (Boissier et al 1961).

\section{Inclined Screen Test:}

Plain glass was used to assess this test. Groups of mice $(n=8)$ were left on a plain glass, inclined at $30^{\circ}$. The mice, which tried to move out of the plane glass without sliding off, were used for the test. The test was performed at 15 and 30min after administration of B. pinnatum and diazepam and normal saline as control drugs. (Rudzik et al 1973)

Anticonvulsant activity: Picrotoxin (5mg/kg i.p.) was injected into the groups of mice $(\mathrm{n}=8)$ pre-treated 30 min earlier with control vehicle or $B$. pinnatum leaf extract $(50,100$ and $200 \mathrm{mg} / \mathrm{kg})$. The tonic convulsion and the mortality were recorded in each group (Soaje Echague and Lim 1962).

Antagonism to Strychnine - induced convulsion: Control vehicle or $B$. pinnatum leaf extract (in different doses) was injected to groups of mice $(n=8)$ $30 \mathrm{~min}$ before administration of strychnine $(4 \mathrm{mg} / \mathrm{kg}$ 
i.p.). The number of tonic convulsion and death were recorded after 4h. (Rudzik et al, 1973).

Statistical Analysis: Results were expressed as Mean \pm SEM. The significance of difference between means was determined by student's $t$-test and the results were regarded as significant at $\mathrm{p}<0.05$.

\section{RESULTS AND DISCUSSION}

The aqueous leaf extract of $B$. pinnatum in dosage up to $20 \mathrm{~g} / \mathrm{kg}$ did not cause any mortality in groups of mice during the $24 \mathrm{~h}$ period after injection. The animals treated with 100 and $200 \mathrm{mg} / \mathrm{kg}$ showed quite significant decrease in locomotor's activity, lasting for about $1 \mathrm{~h}$. However, there was no ptosis at these doses; the lethal dose (LD) at $50 \%$ was $641.2 \mathrm{mg} / \mathrm{kg}$ after $24 \mathrm{~h}$. The exploratory activity of the aqueous leaf extract of B. pinnatum decrease significantly at 100 and $200 \mathrm{mg} / \mathrm{kg}$. (Table1). The extract produced an increase in sleeping time induced by pentobarbitone.
This increase was in dose-dependent manner significantly at 100 and $200 \mathrm{mg} / \mathrm{kg}$ (Fig. 1).

Similarly in chimney, climbing and inclined screen tests, there was a significant loss of coordination and decrease muscle tone in animals treated intraperitoneally with $B$. pinnatum aqueous extract in a dose dependent fashion (Table 2). The treatment with $B$. pinnatum extract, is also able to cause a doserelated delay of the onset in tonic and picrotoxin, even if it was unable to prevent convulsion, an inhibition of mortality was also observed with 100 and $200 \mathrm{mg} / \mathrm{kg}$ (Table 3)

The result of the present study indicates that the crude extract of the $B$. pinnatum leaf produced a significant alterations in general behaviour pattern, reduction in spontaneous mortality, potentiation of pentobarbitone-induced sleeping time in a dosedependent fashion. This is similar with the findings of Fujimori (1995) who proposed that the enhancement of barbital hypnosis is a good index of CNS depressant activity (Fujimori, 1995).

Table 1: Effect of aqueous leaf extract of B pinnatum, chlorpromazine \& Diazepam on Head-dip and evasion tests in mice

\begin{tabular}{lccc}
\hline Treatments & Dose $(\mathbf{m g} / \mathbf{k g})$ & No of Head Dips in 5min & No remaining in box After 5min \\
\hline Normal saline & 1 & $15.2 \pm 0.1$ & 0 \\
Extract & 50 & $13.4 \pm 0.3$ & 2 \\
Extract & 100 & $10.4 \pm 0.2$ & $3^{*}$ \\
Extract & 200 & $6.8 \pm 0.2$ & $6^{* *}$ \\
Chlorpromazine & 4 & $5.5 \pm 0.1$ & 0 \\
Diazepam & 1 & 0 & $6^{* *}$ \\
\hline
\end{tabular}

Value are expressed as mean $\pm S E M(n=8) * p<0.05 ; * * p<0.01$ compared with control.

Table 2: Effect of aqueous leaf extract of B pinnatum and Diazepam on muscle tone (Chimney, inclined screen and climbing text) in mice.

\begin{tabular}{lcccc}
\hline Treatments & $\begin{array}{l}\text { Dose } \\
(\mathbf{m g} / \mathbf{k g})\end{array}$ & $\begin{array}{l}\text { \% of failure in } \\
\text { Chinney test }\end{array}$ & $\begin{array}{l}\text { Time of sliding off the screen in } \\
\text { inclined screen test }(\mathbf{m i n})\end{array}$ & $\begin{array}{l}\text { Climbing time of mice in } \\
\text { climbing test (min) }\end{array}$ \\
\hline Normal saline & 1 & 0 & $60.4 \pm 0.5$ & $6.2 \pm 0.1$ \\
Extract & 50 & 0 & $38.5 \pm 6.1$ & $1.7 \pm 0.8$ \\
Extract & 100 & 0 & $25.2 \pm 0.3$ & $14.5 \pm 1.1$ \\
Extract & 200 & 0 & $6.0 \pm 0.2$ & $28.0 \pm 2.0$ \\
Diazepam & 1 & $80^{* *}$ & $3.8 \pm 0.4$ & $25.5 \pm 3.1$ \\
\hline
\end{tabular}

Value are expressed as mean $\pm S E M(n=8) * p<0.05 ; * * p<0.01$ compared with control. 
Table 3:

Effect of aqueous leaf extract of B pinnatum and phenobarbitone on strychnine and Pic rotoxin-induced convulsion in mice.

\begin{tabular}{|c|c|c|c|c|c|}
\hline \multirow[t]{2}{*}{ Treatments } & \multirow[t]{2}{*}{$\begin{array}{c}\begin{array}{c}\text { Dose } \\
(\mathrm{mg} / \mathrm{kg})\end{array} \\
\end{array}$} & \multicolumn{2}{|c|}{ Duration of tonic convulsion (min) } & \multicolumn{2}{|c|}{$\%$ Protection } \\
\hline & & Strychnine & Picrotoxin & Strychnine & Picrotoxin \\
\hline Normal saline & 1 & $22.2 \pm 0.2$ & $6.2 \pm 0.2$ & 0 & 0 \\
\hline Extract & 50 & $2.3 \pm 0.4$ & $9.1 \pm 0.4$ & 0 & 0 \\
\hline Extract & 100 & $6.8 \pm 0.5$ & $14.2 \pm 1.1$ & 0 & 15 \\
\hline Extract & 200 & $13.8 \pm 0.2$ & $20.1 \pm 1.2$ & 0 & $25^{*}$ \\
\hline Diazepam & 1 & $14.0 \pm 0.6$ & $20.3 \pm 1.1$ & $87.5^{* *}$ & $87 * *$ \\
\hline
\end{tabular}

The extract also produces a significant decrease in exploratory behaviour pattern as evident from the results of head-dip, climbing, and evasion tests. Furthermore the aqueous extract of $B$. pinnatum produces minor anticonvulsant effect by delaying seizure produced by strychnine and picrotoxin.

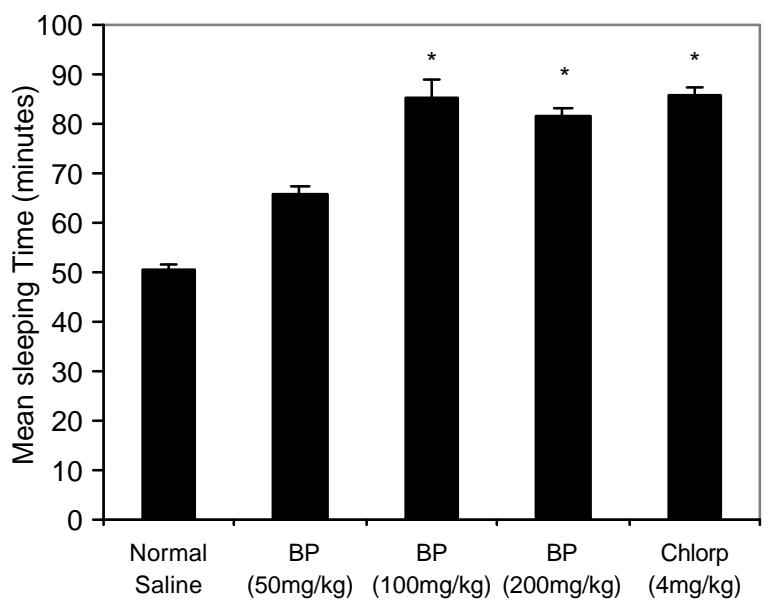

Treatment

Fig. 1.

Effect of aqueous leaf extract of $B$ pinnatum (BP) and chlorpromazine on Pentobarbitone-induced sleeping time in mice. Value are expressed as mean $\pm \operatorname{SEM}(\mathrm{n}=8)$. $\mathrm{p}<0.05$ compared with control

It was however more efficacious against picrotoxininduced seizure where protection was observed in about one-quarter of mice, an effect which indicates that $B$. pinnatum aqueous extract might produce its central nervous system depressant action as consequence of its GABAergic and less importantly, glycinergic transmission, since picrotoxin is a selective $\mathrm{GABA}_{\mathrm{A}}$ receptor antagonist (Rang et al 1996) while strychnine antagonizes the inhibitory spinal cord and brainstem reflexes of glycine (Yemitan et al 2001).

The result of this study is consistent with the report of Pal and Nag (1999) in which there was a significant reduction in the CNS activity in the mice treated with methanolic fraction of B. pinnatum.

The anticonvulsant effect of the aqueous leaf extract of $B$. pinnatum observed in our study was contrary to the result of Pal and Nag (1999) which showed either a decrease or no effect on the pentylene tetrazole -induced convulsion or strychnine -induced convulsion in their study.

One of fundamental difference in the present study and that of Pal and Nag (1999) is the method of preparation of the extracts. The report of Pal and nag (1999) used methanolic extract and higher doses while the present study used only crude aqueous leaf extract of $B$. pinnatum with lower doses.

The difference in the results of the present study and that of Pal and Nag (1999) could therefore be due to the difference in the preparations, and other watersoluble constituents of the extract. Ethanol/Methanol generally can modify the activity of neurons in the CNS including neocortex (Soldo et al., 1998). Furthermore alcohol is also known to have depressant effect on respiratory-related hypoglossal nerve output in humans as well as other mammals (Krol et al., 1984, Serima et al., 1982, Gibson and Berger 2000)

It is possible therefore that the inhibitory effect of methanolic extract of $B$. pinnatum on the CNS activities observed in Pal and Nag (1999) study could be due at least partly to the effect of methanol and partly to the constituent of the B.pinnatum with its attendant higher dose.

Previous phytochemical evaluation of the leaf extract of B.pinnatum revealed that it contains bryophyllum A, B and $\mathrm{C}$, a potent cytotoxic bufadienolide orthoacetate. (Yamagishi et al., 1989, 
1998).

Bufadienolide has been reported to be poisonous, and it is similar to cardiac glycoside poisoning that occurs from ingestion of various plant and animal toxins (Radford, 1986). Several studies shows that bufadienolide toxin is manifested primarily by digitalis toxicity-like cardiac effects, including bradycardia, atrioventricular conduction block, ventricular tachycardia, ventricular fibrillation and sudden death (Radford 1986). Although we did not isolate bufadienolide, and its effect was not also measured in this study. Hwever the CNS depressant activity of aqueous leaf extract of B.pinnatum observed in our study could be due to the presence of bufadienolide and other water soluble constituents in this extract.

Further studies may be necessary to elucidate the phytochemistry, and mechanism of action of B.pinnatum.

\section{REFERENCES:}

Akinpelu D.A. (2000): Anti-microbial activity of Bryophyllum pinnatum leaves. Fitoterapia 71:2:193-194

Balzer G (1949): Bryophyllum. Ein Beitrag zu seina Pflanzen-morphologie. Berlin-Kleinmachnow: Gartenverlag $\mathrm{GmbH}$.

Boissier JR, Dremont C, Robins R, Pagny J (1961): Tentative de pharmacology previsionelle dans de domain de neurole ptiquere: actions sedative centralle et adrenolytique de la N-(dimethoxy - 3, 4, phenethyl) $\mathrm{N}$ (Chloro-2phenyl) piperazine Arch. Int. Pharmacodyn 133:29-32

Brubacher JR, Lachmaher D, Ravikumar PR (1999): Efficacy of digoxin specific fab fragments (Digibina) in the treatment of food venom poisoning. Toxican 37:931-942.

Costa S, Jossang A, Bodo B (1995): Propietes biologiques et phytochiie des kalanchoe pinnata. In: Boiteau P, allorgeBoiteau L, editors. Kalanche des Madagacar. Systematique, ecophysiologie et phytochimie. Paris: Karthala; 1995, p 219 - 35

Dorr M, Joycee D. Porsolt RD, Steinberg H, Summerfield A, Tomkiewiez M (1971): Persistence of dose-related behaviour in mice. Nature 231:121-123

Engler A (1926): Die naturrlichen Pflanzenfamilien nebst ihren Gatttugen und wichtigsen Arten insbesondre der Nutpflanzen. Leipzig: W. Engelmann, 1926, p 402 - 12.

File SE, and Wardril AG (1975): Validity of head dipping as a measure of exploration in a modified hole-board. Psychopharmacology 44:53-59.

Fujimori H (1995): Potentiation of barbital hyponosis as an evaluation method for CNS depressant. Psychopharmacology 7:374-377.
Gibson IC and Berger AJ (2000): Effect of Ethanol upon respiratory-related Hypoglossal Nerve ouput of Neonatal rat Brain stem slices. J. Neurophysiol 83;333-342

Gill LS (1992): Ethno-medical uses of plant in Nigeria UNIBEN Press p.46

Irwin S (1962): Drug screening and evaluation procedures. Science 136:123-136

Krol RC, Knuth SL, and Barlett JR (1984): Selective reduction of genioglossal muscle activity by alcohol in normal human subjects. Am Rev. Respir. Dis. 129:247-250 Marriage PB and Wilso DG (1971): Analysis of the organic acids of Bryophyllum calycinum. Can. J. Biochem. 49: 282 - 95

Mehta Bhat JU (1952): Studies on Indian medical plant II; bryophyllin, a new antibacterial sustance from the leaves of Bryophyllum, Calyciunum Salsib.

J. University Bombay 21:21-25

Miller LC and Tainter ML (1944): Estimation of the LD50 and its error by means of logarithmic probit graph paper 24:839-840.

Misra S and Dixit SN (1979): Anitfungal activity of leaf extract of some higher plants. Acta Botanica Indica 7:147150

Nwabuisi C (2002): Prohylactic effect of multi-herbal induced in mice. East Afri. Med. Journal. 79(7) 343-346

Ojewole JAO (2002): Antihypertensive properties of Bryophyllum pinnatum (Clam ) Oken) leaf extracts. Am J. Hypert. 15(4) A34-A39.

Oliver-Bever B. (1983): Medicinal plants in trpical west Africa. III Antinfection therapy with higer plants. J. Ethnopharmacology, 9: 1 - 83

Pal S and Nag Chaudhuri AK (1989): Preliminary studies on the anti-inflammatory and analgesic activities of Bryophyllum pinnatum (Lam). Med Sci Res. 17:561-562

Pals S and Nag Chaudhuri AK (1990): Anti-inflammatory action of Bryophullum pinnatum leaf extract. Fitoterapia 61: 527-533

Pal S and Nag Chaudhuri AK (1991): Studies on the antitulcer activity of a Bryphyllum pinnatum leaf extract in experimental animals. J. Elhnopharmacol 33:97-102

Pal S Nag Chaudhuri AK (1992): Further studies on the anti-inflammatory profile of the methanolic fraction of the fresh leaf extract of Bryophyllum pinnatum. Fitoterapia 63:451-459.

Pal S, Sen T and Nag Chaudhuri AK (1999): Neuropsychopharmacological Profile of the Methanolic fraction of Bryophyllum pinnatum leaf extract. J.Pharm. Pharmacol 51:313-318.

Radford DJ. Gillies AD, Hinds JA, (1986): Naturally accruing cardiac glycoside. Med. J. Aust. 144:540-544.

Rang HP, Dale MM, Ritter Jm (1996): Chemical transmission and drug action in the central nervous system. In Pharmacology $3^{\text {rd }}$ ed. Churchill Livingstone. Edinburgh. Pp 491-561. 
Rudzik AD, Henter JB; Tag AH, Straw RN, Friis W (1973): Triazolobezodiazepine, a new class of Central Nervous System depressant compound. The Benzodiazepines Reven Press. New York pp 286-298

Scrima L. Broudy M, Nay KN, and Cohn MA. (1982): Increased severity of obstructive sheep apnea after bedtime alcohol ingestion, diagnostic potential and proposed mechanism of action. Sleep 5:318-328

Soaje - Echaque E, Lim RKS (1962): ANTICONVULSION activity of some carbonyl ureas. J. Pharmacol Exp. Ther. 138:224-228

Soldo BL, Proctor WR and Dunwiddie TV (1998)

Ethanol selectively enhances the hyper-polarizing component of neocortical neuronal responses to locally applied GABA. Brain Res: 800:187-197

Turner RA (1965): In: Screening Methods in Pharmacology 113-117. Academic Press, NY and London pp101 -118, 87-89.
Wakeel OK, Aziba Pl, Ashorobi RB, Umukoro S, Aderibigbe AO and Awe EO (2004). Neuropharmacological activities of ficus platyphylla stem bark in mice. Afr. J. Biomed Res. 5 -78.

World Health Organisation (1996): WHO Guideline for the Assessment of herbal Medicines, WHO expert committee on specification for pharmaceutical preparation. Technical Report series No 863. Geneva.

Yamagishi T, Yan X2, Wu RY, Mc Phail MC, Lee KH (1989): Antitumor agents, 110. bryophyllum $B$, a novel potent cyto toxis bufadienolide from Bryophyllum pinnatum. J. Nat. Prod. 52(5):1071-1079

Yei CC and Deng JF (1993): Toad or toadcake intoxication in Taiwan, report of four cases.

Yemitan OK, Ajibade AM and Adeyemi OO (2001): Anticonvulsant activity of Dalbergia Saxatilis. NJA4:3340 